\title{
OS ASPECTOS DA FIDELIDADE PARTIDÁRIA E A HERMENÊUTICA CONSTITUCIONAL DA RESOLUÇÃO 22.610/2007 DO TRIBUNAL SUPERIOR ELEITORAL
}

\author{
Danilo Suniga Braghin, Cesar Augusto Raminelli \\ Universidade do Oeste Paulista, Curso de Direito, Presidente Prudente, SP. E-mail: danilobraghin@hotmail.com
}

\section{RESUMO}

O presente artigo trata de apontar: os aspectos da fidelidade partidária, e sua importância de delimitar barreiras que oprime atitudes que surjam em desencontro com os princípios ideológicos de partidos políticos. Partindo da idéia de que, para concorrer a uma eleição, é requisito estar filiado a um partido político, nasce à fidelidade partidária. Sendo, portando, um instrumento que garante o efetivo cumprimento do mandato, caso o detentor do mesmo descumpra as normas, poderá incorrer em uma sanção, a perda do mandato eletivo pelo mandatário infiel. Diante da contenda, o TSE editou a Resolução 22.610/2007, dando jurisdição a si mesmo para ordenar a perda de mandado eletivo por infidelidade partidária, gerando acalorados debates entre os estudiosos de plantão, pois estes alegam que a resolução editada pelo Tribunal Superior Eleitoral é inconstitucional, em virtude de que a perda de mandato por infidelidade partidária não estava expressa no art. 55 da Constituição Federal.

Palavra-Chave: Partidos Políticos, Fidelidade Partidária, Inconstitucionalidade, Pleito Eleitoral, Mandato Eletivo.

\section{ASPECTS OF PARTY LOYALTY AND THE CONSTITUTIONAL HERMENEUTICS OF RESOLUTION 22,610/2007 FROM THE SUPERIOR ELECTORAL COURT}

\begin{abstract}
This article is to point out: the aspects of party loyalty, and its importance to define barriers that oppress attitudes arising in disagreement with the ideological principles of political parties. Starting from the idea that to run for an election is required to be affiliated to a political party, is born the party loyalty. Being, whatever, an instrument which ensures the effective fulfillment of the mandate if the mandate holder fails to comply with the rules may incur a penalty, the loss of elective office of the unfaithful agent. Before the contest, the TSE issued Resolution 22,610 / 2007, giving jurisdiction to itself to order the loss of elective mandate due to party unloyalty, generating heated debates among scholars on duty, since they argue that the resolution issued by the Supreme Electoral Court is unconstitutional, due to the loss of office by party unloyalty was not expressed in art. 55 of the Federal Constitution.
\end{abstract}

Keywords: Political Parties, Party Unloyalty, Unconstitutionality, Electoral Polls, Elective Mandate. 


\section{INTRODUÇÃO}

O estudo desse trabalho é voltado a uma análise do instituto da fidelidade partidária no vigorante ordenamento jurídico brasileiro, noticia sua importância em combater a migração de políticos eleitos por determinado partido a outras agremiações. As constantes trocas que existiam antes do surgimento da Resolução 22.610/2007, do Tribunal Superior Eleitoral foram amenizadas, mas seu surgimento trouxe vários conflitos entre doutrinadores e estudiosos.

Esse artigo busca elucidar as controvérsias quanto à constitucionalidade da resolução 22.610/2007, do Tribunal Superior Eleitoral, concluindo ao final que, na atual fase política que vivemos a fidelidade partidária não só é benéfica, mas acima de tudo, contribui para o fortalecimento da democracia brasileira. Porém, a forma pela qual foi instituída a fidelidade partidária acabou ferindo a Constituição Federal.

Entretanto, para ilustrar as dúvidas que pairem no ar, é necessário refletirmos nos modos que são editadas as normas brasileiras, porque ao elaborar uma norma é imprescindível seguir as regras que são impostas pelo o ordenamento jurídico vigente. Pois, às vezes o caminho percorrido pode violar diretamente o princípio da Supremacia das Normas Constitucionais e da Tripartição dos Poderes.

\section{METODOLOGIA}

O presente estudo foi desenvolvido a partir de levantamentos bibliográficos, leituras e fichamento. Os dados coletados foram confrontados, interpretados e discutidos dialeticamente para se chegar ao posicionamento defendido.

\section{DISCUSSÃO: PARTIDOS POLÍTICOS}

No mundo contemporâneo, os partidos políticos tornaram-se essenciais para o funcionamento do complexo mecanismo democrático. Para se ter noção da penetração e influência dessas entidades, basta dizer que detêm o monopólio do sistema eleitoral, chegando a definir o perfil assumido pelo Estado. Não há, com efeito, representação popular e exercício do poder estatal sem a intermediação partidária, (Gomes, 2014).

Segundo Gomes (2014, p.93),

Compreende-se por partido político a entidade formada pela livre associação de pessoas, com organização estável, cujas finalidades são alcançar e/ou manter o poder político-estatal e assegurar, no interesse do regime democrático de direito, a autenticidade do sistema representativo, o regular funcionamento do governo e das instituições políticas, bem como a implementação dos direitos humanos fundamentais. 
Nesse diapasão, temos a idéia do que seja um partido político e sua importância no meio social, porque é através das siglas partidárias que temos indicações de pessoas aptas a representar a sociedade, dentre os limites de atuação de cada representante. Cada partido tem seu estatuto próprio, onde é tratada a forma como deverá ser realizada sua política, bem como a formato que seus filiados deveram se comportar diante da agremiação.

Os partidos políticos foram instituídos no Brasil com propósito de tornar sua ideologia em verdade real dentro do sistema democrático de direito, mas como vivemos em um país sistematicamente desinformado, os propósitos não foram alcançados, pois os representantes dos atuais partidos não seguem a ideologia da agremiação à qual estão filiados, sendo o partido uma mera formalidade para uma candidatura.

\section{FIDELIDADE PARTIDÁRIA}

A temática da fidelidade partidária há tempos vem provocando acalorados debates no cenário político. Seus defensores sustentam que ela fortalece a ligação entre a vontade do eleitor e o exercício do mandato por parte de seu representante. Seus opositores alegam que ela enseja uma ditadura dos partidos, na qual burocracias não eleitas prevalecem em detrimento de parlamentares ungidos pela vontade popular, (VELLOSO, 2014).

A fidelidade Partidária dispõe que o parlamentar que tem seu mandato, precisa concorrer às eleições por meio de uma legenda partidária. Quando este deixar o partido, perde automaticamente a função ou cargo em virtude do partido que concorreu ao pleito eleitoral.

De acordo com a Carta Magna de 1988, a fidelidade partidária deveria ser imposta pelo estatuto do partido, conforme dispõe o (Art. 17, § 1ํํ) da Constituição (TENÓRIO, 2014).

O referido autor explica que até o ano de 2007 o entendimento era que o próprio partido redigisse seu estatuto dispondo as sanções disciplinares. Continua em suas argumentações explorando o entendimento do Tribunal Superior Eleitoral e do Supremo Tribunal, onde estes restringiam o alcance da fidelidade partidária, contribuindo para que não fosse causa de perda de mandato a infidelidade partidária.

Nesse contexto, muitos políticos aproveitando dessa autorização legal, não seguiam a ideologia partidária, muitas das vezes traindo a própria agremiação pela qual foram eleitos para defender ideologia de partidos não aliados.

Em razão disso, o então Partido da Frente Liberal - PFL (atual Democratas - DEM) moveu uma Consulta ao TSE (Consulta $\mathrm{n}^{\circ}$ 1398/DF), indagando ao aludido órgão a quem incumbiria o mandato eletivo em caso de pedido de cancelamento de filiação ou de mudança do candidato 
eleito por um partido para outra legenda. O tribunal entendeu que o mandato concerne ao partido e não ao político eleito.

Assim sendo, os partidos políticos solicitaram, a Mesa da Câmara dos Deputados para que este declarasse a vacância dos mandatos dos Deputados que se desfiliaram após a eleição, mas o pedido foi recusado pela consultoria da Câmara, com base no artigo 55 da CF/88.

Com a negativa, foram impetrados alguns Mandados de Seguranças perante a Suprema Corte (STF), circunstância que, em 04 de outubro de 2007, esta Corte referendou o entendimento do Tribunal Superior Eleitoral, de que o mandato pertence ao partido e não ao politico. Além disso, determinou que o TSE editasse uma resolução.

Fundado nos precedentes citados, o TSE editou a Resolução 22.610/2007, voltada a disciplinar o processo de perda de cargo eletivo, bem como a justificação de desfiliação partidária.

\section{INCONSTITUCIONALIDADE}

Com o advento da Resolução 22.610/2007 do Tribunal Superior Eleitoral, começaram os conflitos, pois muitos autores entenderam que a mesma não tem fundamentação jurídica, e alguns insistem em dizer que o Superior Tribunal Eleitoral cometeu o Ativismo Constitucional, ou seja, deixou sua função de judiciário para desempenhar a função de legislativo, (DANTAS, 2010).

A resolução editada pelo Tribunal Superior Eleitoral não foi unânime, pois houve voto em contrário, e com isso faz necessário transcrever o voto do Ministro Marcelo Ribeiro no presente estudo (VELLOSO, 2014).

Segundo Velloso (2014, p 131),

O Ministro Marcelo Ribeiro, o único ministro que votou de forma contrária à fidelidade, dispôs que não há dispositivo normativo expresso na Constituição de 1988 autorizando a perda de mandato ao parlamentar que se transferiu de um partido para outro. Uma homenagem ao princípio da legalidade. Continuando o pensamento produzido em seu voto, afirma basear-se na indelével missão exercida pelos componentes do Poder Legislativo, cominando que as possibilidades de perda de mandato apenas podem ser delineadas no Texto Constitucional, dotando essas normas com sua supra legalidade. Assim, outros casos de perda de mandato não podem ter validade, seja por intermédio de normas infraconstitucionais, seja por interpretações praeter legem. As únicas possibilidades de perda de mandato parlamentar, ostentando natureza sancionatória, foram firmadas no art. 55 da Constituição, e em nenhuma delas existe à fidelidade partidária. 
O Ministro se pautou diante do principio da legalidade imposto na Constituição Federal, arrazoando também que o dever de legislar é do poder legislativo. Portanto, para delinear a perda de mandato por infidelidade partidária é preciso que os legisladores criem emenda à Constituição Federal. Deu ênfase que as únicas possibilidades de perda de mandato foram firmadas no art. 55 da Constituição Federal (VELLOSO, 2014).

No mesmo sentido esclarece DANTAS (2010)

Na realidade, esse instrumento normativo editado pelo TSE, disciplinador da perda de cargo eletivo, utilizando uma terminologia atribuída a Clèmerson Merlin Clévin, não passa pelo filtro constitucional, pois fere o princípio da separação dos poderes insculpido no art. 2o da Constituição da República. Nesse caso, o Poder Judiciário usurpou as funções legislativas do Congresso Nacional, especialmente os arts. 22, I, 5a figura, e 48 da CF, pois àquele Poder cabe interpretar o texto constitucional e as leis pré-existentes no País, ampliando ou restringindo suas normas, nunca legislando positivamente. Inovar, ou seja, trazer ao mundo jurídico, novas regras de convivência política e social é atribuição do Poder Legislativo.

No que diz a respeito à inconstitucionalidade da infidelidade partidária, Canotilho (apud DANTAS, 2010) cita que:

Essa iniciativa do TSE fere um princípio de interpretação constitucional denominado, por J. J. Gomes Canotilho, de princípio da unidade da Constituição que, segundo esse doutrinador: [...] quer significar que a constituição deve ser interpretada de forma a evitar contradições (antinomias, antagonismos) entre suas normas. Como "ponto de orientação", "guia de discussão" e "fator hermenêutico de decisão", o princípio da unidade obriga o intérprete a considerar a constituição na sua globalidade e a procurar harmonizar os espaços de tensão existentes entre as normas constitucionais a concretizar [...]. Daí que o intérprete deva sempre considerar as normas constitucionais não como normas isoladas e dispersas, mas sim como preceitos integrados num sistema interno unitário de normas e princípios.

Dispõe o art. 55 da Constituição Federal de (1988) que:

Art. 55. Perderá o mandato o Deputado ou Senador:

I - que infringir qualquer das proibições estabelecidas no artigo anterior;

II - cujo procedimento for declarado incompatível com o decoro parlamentar;

III - que deixar de comparecer, em cada sessão legislativa, à terça parte das sessões ordinárias da Casa a que pertencer, salvo licença ou missão por esta autorizada;

IV - que perder ou tiver suspensos os direitos políticos;

V - quando o decretar a Justiça Eleitoral, nos casos previstos nesta Constituição;

VI - que sofrer condenação criminal em sentença transitada em julgado. 
Como também dispões o Art. 17. § 1ํ, da Constituição Federal:

Art. 17. É livre a criação, fusão, incorporação e extinção de partidos políticos, resguardados a soberania nacional, o regime democrático, o pluripartidarismo, os direitos fundamentais da pessoa humana e observados os seguintes preceitos:

$\S 10$. É assegurada aos partidos políticos autonomia para definir sua estrutura interna, organização e funcionamento e para adotar os critérios de escolha e o regime de suas coligações eleitorais, sem obrigatoriedade de vinculação entre as candidaturas em âmbito nacional, estadual, distrital ou municipal, devendo seus estatutos estabelecer normas de disciplina e fidelidade partidária. (Redação dada pela Emenda Constitucional no 52, de 2006).

Notamos, pelo dispositivo mencionado, que flui inteiramente da Constituição Federal para os estatutos partidários a ordem para que as agremiações partidárias prevejam normas de fidelidade e disciplina partidária, evidentemente com a coerente penalidade por tais infrações, penalidades essas, no entanto, da esfera de conveniência e oportunidade dos próprios partidos políticos, sem que o Judiciário possa adentrar no mérito de sua discricionariedade (DANTAS, 2010).

Ficando claro que inexiste na Constituição Federal artigo que trata da perda de mandato eletivo por infidelidade partidária, assim sendo, segundo o autor, a Resolução 22.610/2007 é inconstitucional. Porém, não foi esse o entendimento do STF, pois a mesma foi objeto de análise pela Suprema Corte, sendo declarada sua constitucionalidade (DANTAS, 2010).

\section{CONCLUSÃO}

Por meio desse artigo pode-se perceber a importância da fidelidade partidária, sendo ela umas das maiores aliadas para o fortalecimento dos partidos políticos, uma vez que com o surgimento da resolução 22.610/2007 do Tribunal Superior Eleitoral as migrações de políticos eleitos diminuíram, pois estes ficaram vinculados ao partido pelo qual concorreram as eleições, gerando deste modo ampla contenda se o mandato pertence ao partido ou ao parlamentar.

Após o Partido da Frente Liberal - PFL atual (Democratas - DEM) ter realizado a (Consulta $\mathrm{n}^{\circ}$ 1398/DF) junto ao Tribunal Superior Eleitoral, os partidos políticos requereram, à Mesa da Câmara dos Deputados a declaração da vacância do cargo dos legitimados que se desfiliaram após as eleições. Contudo, o pedido não obteve êxito, sendo então recusado pela Consultoria da Câmara, sob o argumento que as causas de perdas de mandatos estão elencadas no art. 55 da Constituição Federal. Porém, com a negativa do requerimento, alguns partidos impetraram Mandados de Seguranças no Supremo Tribunal Federal, esta Corte ao examinar os Mandados referendou o 
entendimento do Tribunal Superior Eleitoral. Assim sendo, mudou sua orientação radicalmente, entendendo que o mandatário infiel poderá perder o mandado outorgado, pertencendo então o mandato à agremiação e não ao político. As novas orientações devem ser observadas, pois tem a finalidade de contribuir com o sistema democrático brasileiro, mas devemos refletir no modo que esta foi elaborada.

Respeitamos as opiniões dos que apóiam a maneira pela qual foi instituída à fidelidade partidária, mas entendemos que a Resolução 22.610/2007 do Tribunal Superior Eleitoral é inconstitucional e fere o art. 55 da Constituição Federal, que prevê um rol taxativo das hipóteses para perda do mandato eletivo no Brasil.

Acatamos o conteúdo instituído pela Resolução 22.610/2007 do Tribunal Superior Eleitoral, mas não compartilharmos de seu processo de elaboração. Por isso, erguemos a bandeira da Reforma Política que está tramitando no Congresso Nacional, para ai então, termos a fidelidade partidária instituída através de Emenda Constitucional.

\section{REFERENCIAS}

BRASIL. Constituição (1988). Constituição da República Federativa do Brasil. Brasília: Senado Federal, 1988.

DANTAS, A, S. Perda de cargo eletivo oriunda de infidelidade partidária: uma questão de hermenêutica constitucional. Resenha @ Eleitoral. Tribunal Regional Eleitoral de Santa Catarina. Disponível em: $\quad$ http://www.tre-sc.jus.br/site/resenha-eleitoral/edicoesimpressas/integra/2012/06/perda-de-cargo-eletivo-oriunda-de-infidelidade-partidaria-umaquestao-de-hermeneutica-constituci/indexe7cf.html> Acesso em 14 de maio de 2015.

GOMES, J.J. Direito Eleitoral. 10. ed. Atlas, 2014.

TENÓRIO, R. A. Direito Eleitoral. ed. São Paulo: Método, 2014.

VELLOSO, C. M. S. Elementos de direito eleitoral. 4. ed. São Paulo: Saraiva, 2014. 